\title{
Optimus Malorum: Giovanni Pico della Mirandola's Complex and Highly Interested Use of Ptolemy in the Disputationes adversus astrologiam divinatricem (1496), A Preliminary Survey
}

\section{H. Darrel RUTKIN ${ }^{1}$}

In this essay I will survey a broad range of Giovanni Pico della Mirandola's explicit mentions of Ptolemy in his long, dense and influential attack on astrology, the Disputationes adversus astrologiam divinatricem of $1496 .^{2}$ Searching the text, I have found that Pico explicitly mentioned Ptolemy's name 376 times in various contexts. We know fully well, however, that Pico was not always explicit or straightforward in how he used Ptolemy, as I have shown elsewhere. ${ }^{3}$ Furthermore, Pico's use of Ptolemy is located at the intersection of two larger issues: [1] The full range of Pico's complex and interested use of authorities overall (mainly astrological, philosophical and theological) in the Disputations, ${ }^{4}$ and [2] the increasing knowledge of Ptolemy's Greek text in the Renaissance.

Although Pico was long dead by the time that the brilliant humanist scholar, Joachim Camerarius, published the Editio Princeps of the Greek text of Ptolemy's Tetrabiblos in 1535, we know that Pico was one of the first scholars to systematically use the Greek manuscripts that Lorenzo de' Medici had collected to philologically critique the earlier Arabo-Latin translations and their associated commentaries. ${ }^{5}$ In this essay, I will explore Pico's explicit mentions of Ptolemy in the Disputations in relation to the authentic Tetrabiblos and Almagest, and the pseudonymous Centiloquium, which Pico thought was authentic. These are

${ }^{1}$ I would like to acknowledge that this article was completed as part of a project that has received funding from the European Union's Horizon 2020 Research and Innovation Programme (GA n. 725883 EarlyModernCosmology), as well as support from the University of Sydney while I was an Honorary Associate in History of Science at its School of History and Philosophy of Science.

2 I use the Latin text that Eugenio Garin edited for the National Edition of Pico's works: Garin, Giovanni Pico. The translation is mine, and will ultimately appear in the I Tatti Renaissance Library. My thanks to the organizers of this marvelous and memorable conference, and especially to David Juste and Dag Nikolaus Hasse for their very helpful responses to a range of queries, and for their valuable comments on the submitted first draft of this essay.

${ }^{3}$ Rutkin, 'The Use and Abuse'.

${ }^{4}$ See (e.g.) Caroti, 'Le fonti medievali'.

5 See Gentile, 'Pico e la biblioteca'. 
the only three Ptolemaic texts that Pico mentions. These three texts were all well known, moreover, and were all, in fact, normal texts of university education, as we can see in the detailed 1405 statutes for the University of Bologna. ${ }^{6}$ After briefly surveying and categorizing Pico's explicit mentions, I will discuss a few examples in greater depth.

Pico was up against tremendous odds in his passionate endeavor to undermine and ultimately eradicate astrology, which was still very much 'normal science' at the time he wrote in the early 1490 s. $^{7}$ Mounting such an attack may seem obvious to us from an early twenty-first-century perspective, but from a late fifteenth-century Renaissance or Early Modern perspective, it would have been a hugely daunting prospect. A resonant analogy would be of someone trying to criticize and destroy Newtonian mechanics in either Cambridge in the middle of the nineteenth century, with respect to both its overall epistemic authority as well as its institutional establishment at the finest universities and learned academies. Pico had his work cut out for him! ${ }^{8}$

Here is another pointed analogy: Despite his profound respect for Ptolemy's work in astronomy, geography, harmonics and optics, Pico criticizing Ptolemy for his astrological writings would be similar to a hypothetical nineteenth-century critic of Newton's respecting him for his work in mathematics, mechanics and optics, but objecting to his work in alchemy. The major relevant difference, however, is that Newton did not publicize his alchemical passions.? Pico was painfully aware of how solidly established and deeply rooted astrology was both conceptually and institutionally, at both the universities - including those he had attended at Bologna, Padua and Ferrara - and throughout a broad spectrum of society, politics and culture. ${ }^{10}$ Astrology was not marginal in any respect. Rather, Pico's attack itself would have been considered profoundly marginal in its time. ${ }^{11}$

${ }^{6}$ See (e.g.) Federici Vescovini, 'I programmi degli insegnamenti'.

See in particular, Boudet, Entre science et nigromance, and in a much shorter compass, my 'Astrology'.

${ }^{8}$ I refer here to Cambridge, UK at Cambridge University and in Cambridge, MA at both Harvard and MIT.

${ }^{9}$ For the most up-to-date information on Newton's alchemy, see William R. Newman, Newton the Alchemist, and his Indiana University website, 'The Chymistry of Isaac Newton': http://webappl.dlib.indiana.edu/newton/index.jsp.

${ }^{10}$ For a lively recent study offering many examples contemporary with Pico, see Azzolini, The Duke and the Stars.

${ }^{11}$ Nevertheless, Pico is part of a long ancient, Arabic and medieval Latin tradition of critics of astrology, including the well-documented cases of Sextus Empiricus, Moses Maimonides, Nicole Oresme and Henry of Langenstein. See most recently Nothaft, 'Vanitas vanitatum'. 
In this context, Pico wrote the Disputations against Divinatory Astrology at the very end of his short but passionate life. ${ }^{12}$ In it, he tried to undermine, destroy and indeed wholly eradicate astrology from the cultural landscape by any means necessary - using many different skills and strategies - in a long and difficult work that has not yet been fully understood in modern scholarship. ${ }^{13}$ Towards this end, in my 2002 Indiana University PhD thesis, I focused primarily on Pico's attack on astrology's natural philosophical foundations in Disputations Book III. ${ }^{14}$ Here I will focus on articulating the contours of Pico's various uses of Ptolemy - astrology's principle ancient authority - towards the very same aim of undermining and destroying astrology. ${ }^{15}$

The Disputations is thus an extremely ambitious work, one part of Pico's larger unfinished project attacking the seven major enemies of the Church. ${ }^{16}$ The only part he certainly wrote (and that still exists) is the Disputations, which Pico did not live to complete, leaving behind a fragmentary manuscript that no longer exists, despite Robert Westman's recent statement to the contrary. ${ }^{17}$ In the Disputations, Pico attacked astrology from many different perspectives, including its natural philosophical foundations and its foundations for practice, inter alia, the doctrines of signs, houses and dignities, all of which were considered essential for astrological prediction. ${ }^{18}$ Here Pico was famously followed a century later by Johannes Kepler in his attempts to reform (not reject) astrology. ${ }^{19}$ Signs, houses and dignities were all employed in the four canonical types of astrological practice: general astrology or revolutions, nativities, interrogations and elections. ${ }^{20}$

Among many other things, Pico was keen to point out that perfectly legitimate mathematical devices otherwise useful for astronomical calculation were

12 See (i.a.) Garin, Giovanni Pico, pp. 3-17. For a splendid evocation of Pico's life, times and works, see Grafton, 'Giovanni Pico'.

${ }^{13}$ For some valuable recent studies, see the essays collected in Bertozzi, Nello specchio del cielo.

${ }_{14}$ Rutkin, Astrology, Natural Philosophy. I also treat this more fully in volume II of my soon-to-be-forthcoming monograph: Rutkin, Sapientia Astrologica, vol. II.

15 This essay draws on and further develops arguments I made in a memorable conference on Ptolemy at Caltech in 2007 organized by Alexander Jones: Rutkin, 'The Use and Abuse'.

16 Garin, Giovanni Pico, p. 3.

${ }_{17}$ Garin, Giovanni Pico, in his introduction, informs us of the state of the manuscript, and Franco Bacchelli provides further information in the Aragno reprint, 'Appunti per la storia'. On the contrary, see Westman, The Copernican Question, n. 55 (p. 528): 'Although the published value may contain a typographical error, Garin, who made a critical comparison with the original manuscript, makes no comment here'. There are many other misprisions in his treatment of Pico, who provides the fulcrum for his larger argument.

${ }^{18}$ See (e.g.) Book VI.

19 See (e.g.) Simon, Kepler.

${ }^{20}$ For a valuable treatment of the range of astrological practices, see Bezza, Arcana Mundi. 
often turned in various ways into astrological predictors, which he characterized as arbitrary signifiers with no foundations in nature. These included the 360 degrees of the zodiac, its twelve 30-degree subdivisions, and their further 60-minute subdivisions. ${ }^{21}$ Pico contrasts these arbitrary man-made mathematical devices (however useful) with actual celestial entities that have real celestial influences, which he certainly believed in, but severely delimited in scope. ${ }^{22}$ For Pico, these celestial-efficient causal factors act only by means of motion, light and heat, within a well articulated Aristotelian understanding of nature, as he discusses in depth in Disputations, Book III. This includes how generation works, as we can see, for example, in De generatione et corruptione II.10, and especially as developed by Aristotle's later commentators, including Albertus Magnus. ${ }^{23}$ In Pico's radical reinterpretation, however, he eliminated the unique nature of each planet's light, and thus its unique influence, as found, for example, in the first two chapters of al-Kindi's deeply influential De radiis stellarum, and Albertus Magnus's commentary on Aristotle's De caelo, II.3.1 ff. ${ }^{24}$ Pico thus attempted to wrench off the by-his-time deeply entrenched astrological superstructure from its still-solid Aristotelian foundations. ${ }^{25}$

One of Pico's main tactics to weaken astrology's epistemic authority was precisely to undermine faith in its major authorities, beginning with Ptolemy, whom he calls (inter alia) the best of the bad ('optimus malorum') and the most learned of the astrologers ('doctissimus astrologorum'). ${ }^{26}$ One way Pico does this is [1] to explicitly, directly and sometimes abusively attack a range of Ptolemy's positive astrological doctrines in the Tetrabiblos and Centiloquium. If Pico can fundamentally shake a pro-astrological reader's faith in Ptolemy, that would be a huge step forward for his project, especially in the Renaissance. By contrast, [2] where Ptolemy ignores - or himself explicitly criticizes or outright rejects - an astrological doctrine, Pico then appropriates his great authority, and thus transforms him, paradoxically, into an anti-astrological

${ }^{21}$ See (e.g.) Disputations VI. 4 and 11.

${ }^{22}$ See my PhD thesis Astrology, Natural Philosophy, chapter 6, and volume II of my monograph Sapientia Astrologica.

${ }^{23}$ Hossfeld, Albertus Magnus; and see my 'Astrology and Magic'.

${ }^{24}$ For the Latin text of al-Kindi, see d'Alverny and Hudry, 'Al-Kindi, De Radiis'; for a partial English translation, see Adamson and Porman, The Philosophical Works, pp. 217-34. For Albert's De caelo, see Hossfeld, Albertus Magnus.

${ }^{25}$ I made this argument in chapter 6 of my PhD thesis Astrology, Natural Philosophy. I support the claims in this paragraph in much greater depth in volumes I and II of my monograph Sapientia Astrologica.

${ }^{26}$ Book I (70, 8 and 6). 
ally. ${ }^{27}$ Another frequent tactic is [3] to shine a harsh and often ridiculing light on the innumerable outright disagreements or conflicting teachings ("pugnantia') between the main astrological authorities. ${ }^{28}$ As by far the most important ancient authority, Pico often used Ptolemy in this context by comparing and contrasting his views with other astrological authorities, primarily ancient and medieval.

In these heated and often sarcastically abusive critical pursuits, Pico regularly deployed his highly developed philological skills to highlight and diagnose - among other things - influential misinterpretations of Ptolemy's doctrines, derived from inaccurate and thus misleading translations. ${ }^{29}$ Sometimes Pico refers explicitly to the Greek manuscripts he knew at first hand, ${ }^{30}$ as well as to Latin translations of Ptolemaic texts and commentaries. Sometimes he even offers his own corrective translations directly from the Greek. Before turning to specific examples, however, I should briefly recall Pico's significant methodological statement in Book II, Chapter 6: if reforming astrology and not suppressing it were his intention, he would have written his book very differently. ${ }^{31}$ The primary purpose of Pico's criticisms, therefore, was to undermine astrology in every possible way, but especially by casting doubt on its foundational doctrines and authorities. His multifold and highly interested uses of Ptolemy played a major role in that process. To their deeper exploration we shall now turn. This essay should be considered a preliminary sounding in deep and richly complex culture-historical waters.

I would now like to analyze some of the ways Pico used Ptolemy by focusing on the controversial theme of astrology's relationship to religion - Pico's central concern in the Disputations - which he treats in some depth, but not systematically. Here I will build up an admittedly incomplete picture, drawn from several disparate chapters, to offer a taste of Pico's approach to this centrally important subject, while focusing on his various uses of Ptolemy. Exploding religion's perceived subordination to astrology was Pico's greatest concern.

27 For Ptolemy as a critic of earlier astrology, see Grafton, 'Giovanni Pico'.

${ }^{28}$ One (of many) examples is in Disputations, VI.3, in which Pico attacks the astrologers for disagreeing among themselves ('inter se pugnent') about the doctrine of the terrestrial houses.

${ }^{29}$ On Pico as a high-level philologist, in addition to Grafton, 'Giovanni Pico', see Gentile, 'Pico filologo'.

30 Some of these are described in Gentile, 'Pico e la biblioteca'.

31 'Quod si docere hic potius astrologiam quam confutare instituissem, funderem manum ad errata iuniorum profitentium hanc artem; sed non hoc meum consilium. Adnotare tamen fortasse aliqua fuerit operae precium, quo magis fiat manifestum non posse eos vera praedicere etiam si verissima essent dogmata astrologorum' (142, 19-24). 
I begin with Book II, Chapter 5, which is entitled: 'How harmful and noxious astrology is to the Christian religion'.32 Pico mentions Ptolemy himself once in this chapter. He begins by strongly stating his overall view of astrology's relationship to religion, and it is not a pretty picture:

Truly, for me reviewing and exploring [...] the enemies of the Church, I do not see where more supplies and more arms are supplied to all of them equally against the truth than from this profession [namely, astrology]. For from this, the fall is easy and headlong into impiety, bad religion, heresies, vain superstition, lost morals and irrevocable evil. For whence will impiety arm itself against the spears of religion better than that divine miracles, by which every religion is primarily confirmed, be referred to the heavens? ?33 $^{33}$

This is very much in line with Pico's statement in the overall Proem that astrology is the mother of all superstitions. ${ }^{34}$

The next passage has the one explicit mention of Ptolemy:

But I have read none of the main writers of astrology who do not subject religion and all laws - and likewise the rest of human affairs - to the configurations of the stars. In the second book of the Apotelesmaton, Ptolemy understands the fact - that in this nation (gens), this god (numen), and in that nation, a different one is worshipped - arose from nowhere else than from the different natures of the stars and constellations that rule these peoples and nations. ${ }^{35}$

The passage in question comes from Tetrabiblos II.3, and here Pico neutrally describes Ptolemy's position. He also mentions Ptolemy's anonymous Greek commentator soon after.

32 'Quam noxia sit astrologia quamque pestifera christianae religioni' $(126,11)$.

33 'Sane lustranti mihi undique omnia et ecclesiae hostes exploranti, non video unde omnibus pariter plus copiarum, plus armorum, adversus veritatem suppeditetur, quam ex ista professione. Hinc enim ad impietatem, hinc ad malam religionem, hinc ad haereses, hinc ad vanam superstitionem, hinc ad perditos mores irrevocabilemque malitiam praeceps et facillimus lapsus. Unde enim se potius adversus tela religionis armabit impietas, quam ut divina miracula, quibus omnis potissimum religio confirmatur, ad caelum pertendat esse referenda?' (126, 13-22).

34 'Est autem haec propria labes omnium superstitionum, quarum non alia professio quam praecepta tradere insaniendi; sed in primis hunc sibi titulum vendicavit astrologia, sicut et inter ipsas superstitiones, quarum mater alumnaque merito existimatur, obtinet principatum' $(38,28-40,1)$.

35 'Ego vero ex scriptoribus astrologiae praecipuis neminem legi qui religionem et leges omnes, ut reliquas res humanas, constellationibus siderum non subiciat. Ptolemaeus, in secundo libro Apotelesmaton, quod apud hanc gentem illud numen, apud aliam aliud coleretur, non aliunde natum intelligit, quam ex varia siderum imaginumque natura populis illis et gentibus imperitante' $(128,13-19)$. 
The next passages to be examined are from Book IV, Chapter 10, which is entitled: 'That bad laws, just as good laws also, are not subjected to the heavens. ${ }^{36}$ Pico mentions Ptolemy five times in this chapter. The first passage develops the material just discussed:

But in general, that both good and bad religions do not depend on the heavens, experience itself sufficiently demonstrates. For some refer the origins and variety of religions to the stars, which rule cities and provinces, as they believe, by their own law. Others refer the origins and variety of religions to what they call the Great Conjunctions of the superior planets, especially of Saturn and Jupiter. The Arabs and Latins follow this opinion, pursuing the tracks of the Arabs. It seems that Ptolemy had approached this, who, as we will declare afterwards, never mentioned these Great Conjunctions. But in the second book of the Apotelesmaton he says that those Asiatics situated to the East and South worship Venus and Saturn, since they are under a triplicity of an arid quality, that is, Virgo, Taurus and Capricorn, which he thinks Saturn and Venus rule. Again, whoever lives between the South and West has Venus and Mars for gods, since they are located under a moist triplicity, which sets Mercury and Venus over them along with Mars. ${ }^{37}$

Here Pico describes more fully what he had just claimed for Ptolemy, namely, that places and their celestial rulers determine which gods are worshipped where. Once again, Pico neutrally and accurately describes Ptolemy's position. This time, however, he does so to refute it. ${ }^{38}$

Now Pico directly attacks Ptolemy's position with an argument from experience:

Now, that opinion of Ptolemy - in which different stars rule different places and peoples in the same manner, so that he would also think that different religious rites exist in different places - is strongly refuted by experience itself: the same stars still rule those provinces lying between the East and South that ruled them formerly, and Venus and Saturn are no longer worshipped there, as they were formerly. Why do these gods rule them? As Ptolemy himself writes, it is because the earthly triplicity, corresponding to Taurus, Virgo and Capricorn, rules those regions, and Venus and

36 'Malas leges, sicuti nec bonas, caelo non subici' (486).

37 'In universum vero tam bonas quam malas religiones a caelo non dependere, ipsa satis experientia demonstratur. Alii enim religionum ortus et varietatem ad sidera referunt, urbibus et provinciis suo quodam, ut ipsi credunt, iure dominantia; alii ad magnas quas vocant coniunctiones planetarum superiorum, Saturni praesertim atque Iovis; et hanc quidem sententiam sequuntur Arabes et Latini, vestigiis Arabum insistentes; illi accessisse videtur Ptolemaeus, qui, ut postea declarabimus, de magnis illis coniunctionibus nullam umquam habuit mentionem. Sed libro secundo Apotelesmaton eos ait ex Asiaticis, qui ad orientem vergunt et meridiem, colere Venerem et Saturnum, quoniam trigono subsint aridae qualitatis, hoc est Virgini, Tauro et Capricorno, quibus ipse putat Saturnum Veneremque dominari; rursus qui inter meridiem habitant et occasum, Venerem atque Martem habere pro numinibus, quoniam humidae triplicitati subiciantur, cui cum Marte, Mercurium et Venerem praeficit' $(486,7-488,1)$.

${ }^{38}$ I will discuss the central doctrine of Great Conjunctions below. 
Saturn are in that triplicity. For so he thought. But this partition of the world with its regions distributed under different triplicities is perpetual, not temporary. Wherefore, what existed at some time will always be the same. Why, therefore, O Ptolemy, does the same religion not remain also in the same places today? Finally, let us conclude this entire chapter by thus inquiring of Ptolemy himself: if different stars were worshipped formerly, among different peoples, from a different rulership of the stars, by the force and power of what star is it effected that no stars today are worshipped in almost any region of the entire world? ${ }^{39}$

This chapter ends with Pico calling Ptolemy out and ridiculing him in a mildly sarcastic manner, another way that Pico used Ptolemy in the Disputations, especially when Ptolemy promoted a doctrine that Pico rejects.

Next I will discuss Book V, Chapter 14, which approaches the subject of religion differently. It is entitled: 'That that which is commonly said to be the true geniture of Jesus is not, and there is no indication in it that he would either die a violent death or be a great prophet'. ${ }^{40}$ In this chapter, Pico only mentions Ptolemy once, and he uses him differently here than before:

What these little diviners (divinaculi) trifle about concerning the geniture of Jesus himself is wont to disturb some people. For he was born, they say, while the first face of Virgo - thus they call decans - was rising, about which Albumasar writes that there is in it a lovely maiden holding two spikes of grain in her hand and nourishing a boy, whom a certain people call Jesus. Thus they think that the miracle of the embodied Word is confirmed by the science of astrology, which finds among the celestial images the Virgin and Jesus. For my part, I am not especially angry with them, since they are accustomed to confirm their religious teachings with such testimonies. Therefore, they think that we will willingly accept these things to cor-

39 'Iam illam Ptolemaei opinionem, quae perinde atque variis locis et gentibus varia sidera dominantur, ita varios etiam ritus religionum in locis existimat, longe magis ab ipsa experientia confutatur. Cum et illis provinciis quae inter orientem iacent et meridiem praesint eadem sidera quae olim illis praesidebant, nec tamen ut olim ibi Venus Saturnusque coluntur. Cur enim haec illis numina dominabantur? Utique, ut ipse scribit Ptolemaeus, quoniam terrena triplicitas, quae constat ex Tauro, Virgine et Capricorno, regionibus illis praeest; illi vero triplicitati Venus et Saturnus. Ita enim ipse existimavit. At partitio haec mundi et regionum, sub aliis atque aliis triplicitatibus distributarum, perpetua est, non temporaria; quare eadem erit semper quae aliquando fuit. Cur non igitur, o Ptolemaee, eadem etiam in eisdem locis hodieque religio durat? Denique totam istam disputationem ita concludamus, Ptolemaeum ipsum interrogantes, si a varia siderum praesidentia apud alias gentes olim alia sidera colebantur, cuiusnam sideris vi ac potestate efficitur ut nulla sidera hodie aliqua fere totius mundi regione colantur' $(488,21-490,8)$.

40 'Eam quae vulgo fertur, veram esse Iesu genituram, nec ex ea indicari illum aut violenta morte moriturum, aut magnum esse prophetam' $(604,1-3)$. For this and other related material, see Pompeo Faracovi, Gli oroscopi di Cristo. 
roborate our religious teachings. But Christian truth has no need for these fables and dreams, among which even the weighty sayings of the philosophers are all but fables. Who has seen these images while their senses were quiet, which an extremely obscure account indicated? Where did either Ptolemy or some ancient ever mention them? These are the tidiest bits of nonsense, these figments of the Arabs, although they refer them back to the Indians, against which we will dispute more broadly in the following book. But Lord Jesus was not born with that virgin ascending, as they say. Otherwise, he would have come into the light almost two hours before midnight, but we have received from Church tradition that he was born at midnight. Wherefore, neither the third degree of Libra, as a certain person says, but rather the tenth occupied the rising point when the most desired of all people arose. ${ }^{41}$

Thus, even if the doctrine of decans were sound, according to Pico's analysis, Jesus in fact had ten degrees of Libra rising and not Virgo at all, let alone its first ten degrees. This would mean that a different decan altogether would be on the ascendant, which would thereby wholly undercut their argument. In this way, Pico uses a properly astrological argument to refute the astrologers, something he said he would do in Book III.1. ${ }^{42}$ As he also said, Pico treats the decans later in greater detail in Book VI, Chapter 16, and he uses Ptolemy there too in the same way, namely, by employing Ptolemy's silence concerning decans to make his own anti-astrological point. It is noteworthy that the counter-argument presupposes some good knowledge of astrology.

The last chapter I will discuss concerning Pico's attempts to decouple religion from astrology is the rather long and involved Book V, Chapter 5, in which

41 'Movere autem solent nonnullos quae de genitura ipsius Iesu nugantur isti divinaculi; natus enim est, inquiunt, prima facie virginis (sic decanos vocant) ascendente, de qua scribit Albumasar, esse in ea virginem formosam duas manu spicas gerentem puerumque nutrientem, quae gens quaedam vocat Iesum. Sic confirmari putant miraculum Verbi corporati per scientiam astrologiae, quae inter caeli imagines Virginem Iesumque repperit. Hic eis equidem non magnopere irascor quoniam solent ipsi sua dogmata talibus testimoniis confirmare, quia putant libenter nos etiam haec recepturos, quibus dogmata nostra corroboremus. Sed non eget his fabulis somniisque veritas christiana, apud quam etiam seria philosophorum paene fabulae sunt. Quis has vidit imagines cui, sensu tacente, ratio illas occultior indicavit? Ubi de illis, vel Ptolemaeus, vel antiquus aliquis umquam fecit mentionem? Meracissimae nugae sunt Arabumque figmenta, quamquam illa referant ad Indos, adversus quas libro sequenti latius disputabimus. At neque ista virgine, ut dicunt, ascendente natus est dominus Iesus, alioquin per duas ferme horas ante mediam noctem in lucem apparuisset, quem ex ecclesiae traditione media nocte natum accepimus; quare nec tertia, ut quidam dicit, Librae pars, sed decima potius, cum oriebatur natorum desideratissimus, horoscopum occupabat' $(604,4-606,11)$.

42 'Atque ipsam hanc nostram opinionem non aliis magis, quam quibus utuntur astrologi contra nos argumentis, asseveratam probabilemque reddemus' (178, 19-21). 
Pico directly confronts the central issue of Great Conjunctions. ${ }^{43}$ Pico mentions Ptolemy 16 times in this chapter, whose title is: 'That the planets joined in Great Conjunctions have no more power than when divided, and that these Great Conjunctions have been found to be something new, born from a bad understanding ("malus intellectus") of Ptolemy": ${ }^{44}$

But even if we grant that planets which have been joined do more than when they are separated toward the great transformations (mutationes) of this world - as he had just argued - nevertheless, we will not grant that this is to be referred back to a conjunction of Jupiter and Saturn, or Mars. We will prove, however - both by reason and the authority of the greatest astrologers - that other planets obtain their power first in these matters. For none of the ancients ever made their judgments on universal transformations of the world via what are called Great Conjunctions. [Firmicus] Maternus says nothing about these, although he was certainly the most curious investigator of astrology. Paulus [Alexandrinus] says nothing; Hephaestion [of Thebes] says nothing; Theophilus says nothing; Astaxarchus says nothing. Ptolemy himself says nothing, whose testimony here will suffice, so that we do not use witnesses against them who are too little known. ${ }^{45}$

Here Pico uses Ptolemy along with some other ancients - and as their spokesperson - to argue against one of contemporary astrology's major doctrines that subordinated religion to astrology. We will now explore how he does so.

First Pico neutrally describes Ptolemy's relevant doctrine:

In the second book of the Apotelesmaton (II.4), teaching in what way general transformations of the world are foreseen, [Ptolemy] refers them all and only to eclipses of the sun and moon. Nothing can be said more rationally [sc. in favour of an astrological doctrine], for universal and great effects ought to be referred to these causes, which are the greatest, universal and efficacious. Moreover, it is admitted by everyone that among the planets two only are of universal efficient causality (efficientia universalis), namely, the sun, and the moon, whose light is none other than the sun's light borne to earth as by a mirror. Wherefore, if any celestial power (virtus) ought

${ }_{43}$ For more on the doctrine of Great Conjunctions, see (e.g.) North, 'Astrology and the Fortunes', and now Hasse, Success and Suppression, pp. 272-89, with a discussion of Pico's critique thereof at pp. 277-78.

44 'Planetas magnis coniunctionibus iunctos non plus posse quam divisos, magnasque istas coniuntiones novum esse inventum de malo Ptolemaei intellectu natum' $(544,18-20)$.

45 'Quod si iunctos planetas plus facere quam separatos ad magnas istius mundi mutationes illis dederimus, non tamen dabimus hoc ad Iovis Saturnique aut Martis coniunctionem referendum, sed obtinere vim primam in istis rebus alia sidera, et ratione et summorum astrologorum auctoritate probabimus. Neque enim umquam aliquis veterum per has, quas isti vocant magnas coniunctiones, de universalibus mundi mutationibus iudicarunt, nihil de his Maternus, quamquam curiosissimus utique astrologiae investigator, nihil Paulus, nihil Ephestion, nihil Theophilus, nihil Astaxarchus, nihil ipse Ptolemaeus, cuius hic nobis testimonium erit satis, ne parum eis notis testibus adversus eos utamur' $(546,22-548,2)$. 
to be thought the origin and cause of universal and great effects, none should be thought other than these. ${ }^{46}$

These views can be much more fully developed from Pico's extensive and penetrating natural philosophical analyses in Disputations, Book III. ${ }^{47}$

He continues:

But I know what they say about Ptolemy, that this was omitted by him in the Apotelesmaton in order not to expose a mystery. For thus Haly, his commentator, writes. But in the Centiloquium, many examples of this thing have been given when, in the $50^{\text {th }}$ verbum, he directs that we should not forget the conjunctions of the planets, in which there is great efficacy; and likewise in the $58^{\text {th }}$ verbum. Then, in the $65^{\text {th }}$, he reminds us of these same matters, transmitting the great teachings of these things in distinguishing the greatest, median and smallest conjunctions. ${ }^{48}$

Here Pico sets up a contrast between Ptolemy's approach in the Tetrabiblos and Centiloquium. He also mentions how Haly, Ptolemy's commentator, ${ }^{49}$ frames the differences as Ptolemy's deliberate choice in the Tetrabiblos in order to protect this major doctrine from careless exposure to the 'hoi polloi'.

Pico now goes on the offensive, setting the tone, as so often, with biting sarcasm. This time, however, it is not directed against Ptolemy himself, but at a very influential — and extremely pernicious - misinterpretation (as he sees it):

I want nothing more than for them to respond to me that, from here on out, either their teachings, whichever seem greater and more admirable, become open to all, or

46 'Is igitur, secundo libro Apotelesmaton, docens qua via generales et mundi mutationes praevideantur, eas omnes refert solummodo in Solis Lunaeque defectus; nec potest dici aliquid rationabilius, nam debent effectus universales et magni in eas referri causas quae maximae, universales et efficaces sint. Est autem confessum apud omnes inter planetas duos esse tantummodo efficientiae universalis, Solem scilicet et Lunam, cuius lumen non aliud quam Solis lumen per eam quasi per speculum, ut sic dixerim, ad terram delatum. Quare, si qua debet caelestis virtus origo et causa existimari effectum universalium atque magnorum, nulla debet potius quam siderum istorum talis existimari' $(548,2-13)$.

${ }^{47}$ See the analysis in my PhD thesis Astrology, Natural Philosophy, chapter 6, and in volume II of my monograph Sapientia Astrologica.

48 'Sed scio quid dicent de Ptolemaeo, omissum hoc ab eo in libro Apotelesmaton ne mysterium proderet. Ita enim scribit Haly eius interpres. Sed in Centiloquio (sic enim vocant) multa eius rei dedisse documenta, cum verbo quinquagesimo eius libri iubeat ne planetarum coniunctiones obliviscamur, in quibus magna sit efficacia; et verbo item tum quinquagesimo octavo, tum quinto et sexagesimo, earundem rerum nos admonet, magna tradens de his praecepta, coniunctionem maximam, mediam minimamque distinguens' $(548,21-550,2)$.

49 The real name of the Centiloquium's commentator is Abū Ja far Aḥmad ibn Yūsuf, and 'Haly' is just a wrong inference by Plato of Tivoli, which contaminated the entire Latin tradition. See Lemay, 'Origin and Success', pp. 103-04. This 'Haly' has nothing to do with and should not be confused with Haly Abenrudian ('Alì ibn Riḍ̂ann), the commentator of the Tetrabiblos. See now also Hasse, Success and Suppression, pp. 370-74, for a clarifying discussion of all three Halys. 
[to admit] that they have emerged from either vain opinions or a false understanding of ancient authors. For what they say - that Ptolemy kept this quiet in the Apotelesmaton to not bring forth a mystery - I am so far from denying this that I believe he also did not bring it forth in the Centiloquium, in which, certainly, he said nothing more about these conjunctions than what he also did not say about the death of Priam or the Trojan war! $!^{50}$

Pico has now set the sarcastic tone for what follows. As we will see, Ptolemy's doctrine is not the problem here. In fact, Pico fully agrees with it. Rather, the problem arises with an extremely influential later misinterpretation of what Ptolemy wrote.

Pico then discusses each text from the Centiloquium in turn, beginning with verbum 50:

Ptolemy's $50^{\text {th }}$ verbum is thus among them, that is, in the common edition (in vulgata editione): 'You ought not to forget that there are 120 conjunctions among the planets. For in these there is a greater knowledge of things that come to be in this world receiving increase and decrease'. In Greek it is thus: 'We should not overlook 119 conjunctions. For among them has been placed a conjunction of those things which come to be in the world of generation and corruption'. ${ }^{51}$

Pico here gives the normal translation of this text in Plato of Tivoli's twelfthcentury version from the Arabic, ${ }^{52}$ and then offers his own slightly but significantly different translation, directly from the Greek.

Pico now has a basis for his own revisionist analysis:

First of all, the barbarous interpretation attributes more to these conjunctions than Ptolemy does[.] [...] Let us ascribe the transformations of lower things, above all, to the greatest conjunctions. Ptolemy certainly did not say that it is of the superior planets, but rather, if what he wrote is both read and understood accurately, it will

50 'Ego vero ab eis responderi nihil potius vellem, ut vel hinc palam omnibus fiat, quaecumque eorum dogmata maiora admirabilioraque videntur, ea vel ex vanis opinionibus, vel ex falsa veterum auctorum intelligentia pullulasse. Nam quod dicunt tacuisse hoc Ptolemaeum in libro Apotelesmaton, ne mysterium proderet, tantum abest ut negem, ut nec in Centiloquio credam proditum ab eo, in quo certe tam nihil magis locutus est de istis coniunctionibus, quam nec de Priami morte aut bello Troianorum' (550, 2-11).

51 'Est quinquagesimus Ptolemaei verbum ita apud eos, hoc est in vulgata editione: "non obliviscaris esse centum viginti coniunctiones, quae sunt in stellis erraticis; in illis enim est maior scientia rerum quae fiunt in hoc mundo suscipientia incrementum et decrementum". Graece est ita: 'Ne praetermittamus centum et decem novem coniunctiones. In his enim posita est coniunctio eorum quae fiunt in mundo generationis et corruptionis' (550, 13-20).

52 The text here is my transcription of Erhard Ratdolt's 1484 Venice edition, Liber Pthole$m e i$. The pages in this edition are not numbered: 'non oblivisceris esse 120 coniunctiones, quae sunt in stellis erraticis; in illis enim est maior scientia eorum quae fiunt in hoc mundo suscipienti incrementum et decrementum'. These are the differences from Garin's text: obliviscaris; number written out (centum viginti); rerum for eorum; suscipientia. The status quaestionis on the various versions of the Centiloquium is Boudet, 'Nature et contre-nature'. 
indicate the contrary to us. For he did not say that there are 120 of these conjunctions, as is commonly said, but only 119 because he does not number the conjunction of the sun and moon with them, so that it would have peculiar privileges, and a singular prerogative, in great and universal transformations. He restores all the rest to a disorderly mass of number and order, so that, among them, one would not rule another in a particular situation. But the barbarous expositors, not paying attention, as if it had been omitted by the fault of the scribes, added the conjunction of the sun and moon. They thought that 120 is to be read, not 119 , which all the Greek codices have, so that, not content with a deviation of the sense, they also corrupted our faith in the letter. ${ }^{53}$

Here Pico makes a philological-critical argument to revise our understanding of this crucial passage. He argues that Ptolemy did indeed have one particular conjunction in mind, but it was of the sun and moon, not Jupiter and Saturn. In fact, the translations from the Arabic all mention 120 conjunctions, and those from the Greek - Pico's, Pontano's and George of Trebizond's - all have $119 .{ }^{54}$

Pico further supports this radical reinterpretation with verba 58 and 65, by arguing that the Greek term ' $\sigma u$ vodos', when unqualified - as we find it in pseudo-Ptolemy's Greek manuscripts - refers only to conjunctions of the sun with the moon $(552,19-554,20)$, that is, to the new moon. ${ }^{55}$ Finally, Pico

53 'Primum plus tribuit istis coniunctionibus barbara interpretatio quam tribuat Ptolemaeus [...]. Sed in quas potissimum maximas quasque rerum inferiorum mutationes referamus superiorum esse siderum, Ptolemaeus certe non dixit, sed potius, si eius dicta recte et legantur et intelligantur, contrariam nobis sententiam indicabunt. Non enim centum et viginti, ut vulgo legitur, has esse dixit coniunctiones, sed solum centum decem et novem, quia his scilicet Solis et Lunae coniunctionem non numerat, ut quae privilegia habeat peculiaria praerogativamque singularem in magnis universalibusque mutationibus; reliquas omnes acervatim in numerum ordinemque redigit, ut inter quas alia aliae singulari nulla conditione praestaret. Quod non advertentes barbari expositores, quasi omissum foret vitio librariorum, Solis et Lunae coniunctionem addiderunt, legendumque centum et viginti, non autem centum decem et novem, quod graeci omnes codices habent, putaverunt, ut non contenti sensus depravatione, litterae quoque fidem adulterarent' $(550,20-552,18)$.

${ }_{54}$ My thanks to David Juste for this information on the Centiloquium.

55 On the face of it, this is neither a sound nor a persuasive argument, since ' $\sigma$ úvo $\delta \circ \varsigma^{\prime}$ ' = 'conjunction' can refer to a conjunction of the sun and moon as well as of the other planets,

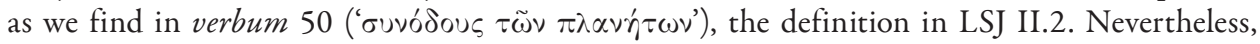
this is, in fact, Ptolemy's normal usage when ' $\sigma \dot{u} v o \delta \circ \xi^{\prime}$ is unqualified in both the authentic Tetrabiblos and Almagest, as well as in the pseudo-Ptolemaic Centiloquium. In the 13 instanc-

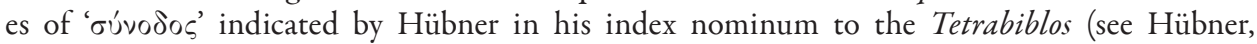

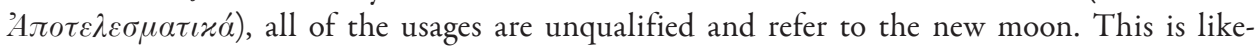
wise the case in the 50 instances in the Almagest identified by the TLG in which one can find three related usages: [1] to the new moon (often along with the full moon); [2] in the phrase 'mean conjunction', in these cases always referring to the sun and moon; and [3] the conjunction of the sun and moon in relation to determining the time of eclipses. My thanks to 
reinterprets greatest, median and smallest conjunctions to mean, respectively, eclipses, the new moon before the sun enters the tropical signs (namely, those of the four seasons), and those for every other month $(554,20-558,11)$, which is truly far-fetched, and has no support in the Tetrabiblos. For Pico, this is Ptolemy's true opinion. Pico attributed the normal view of these conjunctions as of Jupiter and Saturn, on the other hand, to a barbarian, that is, Arabic misinterpretation of Ptolemy's text. Here Pico shows off his philological skills to shine a critical light on a profoundly influential misinterpretation (as he sees it) of Ptolemy's doctrine in the Centiloquium that had hitherto provided an authoritative foundation for Great Conjunctions.

In a full treatment of this interesting and important topic, I would characterize each of Pico's 376 explicit mentions of Ptolemy. Some will fall clearly into well defined categories, others will not. These are some of the more significant categories I have thus far detected: [1] As an example of discord between authorities to undermine faith in an astrological doctrine, with Ptolemy's as one of the conflicting teachings. [2] Pico using Ptolemy's silence or explicit criticism as powerful ammunition to help him attack and/or delimit a range of astrological doctrines. Ptolemy was himself, of course, a major critic of earlier astrology in the Tetrabiblos. [3] Pico also overtly attacks and sometimes ridicules Ptolemy himself for holding a number of astrological doctrines, as well as for other positions, including his purported incompetence as a philosopher. ${ }^{56}$ In short, with Ptolemy in particular, Pico wanted to play it both ways: to hold up Ptolemy as an authority when he supports Pico's position, and to undermine and criticize him when he does not.

\footnotetext{
Alexander Jones for his timely assistance in this matter. In addition to the several unqualified

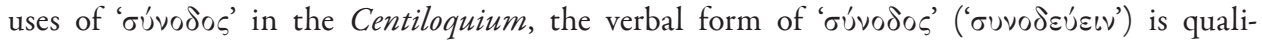

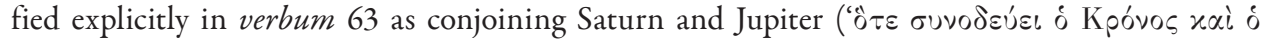
Zeúc'). In verbum 65, pseudo-Ptolemy refers to smallest ('minima'), middle ('media') and greatest ('maxima') conjunctions, but he does not further qualify them. Perhaps these two verba in close proximity inspired the misinterpretation that Pico is attempting to rectify. Finally, the only other usage I could find of a qualified use of ' $\sigma u ́ v o \delta o s$ ' itself in the Greek of any of these three Ptolemaic texts is in verbum 50 in the Greek text of the Centiloquium in Boer, Ka@лós:

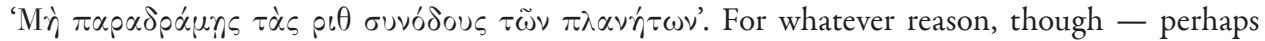
he was using a different Greek manuscript - Pontano does not reflect this qualified usage in his translation: 'Ne praetermittas centum et decem novem coniunctiones'. I use Boer's 1952 Teubner edition of the Greek text of the Centiloquium, and Pontano's Latin translation in the 1531 Basel edition. I also use Heiberg's edition of the Greek and Toomer's English translation of the Almagest, and Hübner's Greek text of the Tetrabiblos and Robbins's English translation in the Loeb Classical Library, as well as a printout from the Thesaurus Linguae Graecae on the various instances of ' $\sigma \dot{v}$ 'vodos' in the Almagest.

${ }^{56}$ Pico treats this theme at Book I (70, 9 ff.).
} 
Pico often used philological-critical arguments towards a range of anti-astrological ends. They were usually deployed with explicit quotations and their often penetrating (if deeply interested) analyses. Sometimes the translations were new and revisionary by Pico himself. He also regularly mentioned Ptolemy along with one or more of his commentaries and/or commentators, including Haly, the anonymous Greek and others, often to highlight their so-called barbarous misinterpretations. In this light, given the broad and impressive display of his much vaunted philological skills - and even though he several times pointed out striking doctrinal differences between the Tetrabiblos and the Centiloquium (as just above) - it is surprising that he never drew the conclusion that one might be spurious.

Furthermore, Pico attacked Ptolemaic doctrine in numerous ways, including by arguing that Ptolemy's own position was misunderstood, which is then not a direct attack on Ptolemy himself, but on a particular (sometimes influential) interpretation, including by his major commentators. This is a place where, if Pico were interested in reform - not rejection - he could have cleared the way back to a more pristine Ptolemaic astrology with later distorting accretions (including such misinterpretations) removed. ${ }^{57}$ We can see this intention with contemporary medically-oriented humanist scholars, including Nicolò Leoniceno, and Giovanni Mainardi, Leoniceno's student and one of the editors of the Disputations, along with Pico's nephew Gianfrancesco. ${ }^{58}$

Especially in the Renaissance, neutralizing or diminishing Ptolemy's stature as an astrological authority would have taken Pico a very long way indeed towards realizing his quixotic goal of suppressing astrology. Success in rebranding a perfectly legitimate and by-his-time well-established scientific astrology as divinatory astrology - that is, as the mother of all superstition and thus the preeminent enemy of the Church - would have completed his overly ambitious goal, but in this he was profoundly unsuccessful, especially in the short term. His ultimate goal, I believe, was to entirely remove astrology from the prophetic airwaves, as it were, especially in an age of widely disseminated annual astrological prognostications that were increasingly available and affordable. ${ }^{59}$ In this

57 We see such a reforming orientation towards astrology in Girolamo Cardano. See Grafton, Cardano's Cosmos.

${ }^{58}$ For Leoniceno, see (e.g.) Mugnai Carrara, La biblioteca di Nicolò Leoniceno. For Mainardi and his role in the complex many-handed process of editing Pico's Disputationes, see Zambelli, 'Giovanni Mainardi', and Farmer, Syncretism. Although the evidence Farmer presents is intriguing, his conclusions should be treated with caution.

${ }^{59}$ For valuable recent scholarship on this important topic, see Green, Printing and Prophecy, and Tur, Hora introitus solis. 
way, the voice of a true divinely-inspired prophet, Girolamo Savonarola, could be heard without so much noisy and persuasive competition. ${ }^{60}$

To characterize astrology as divinatory - as Pico does in the Disputations - seems perfectly unobjectionable to us, but would have been taken quite differently by most of Pico's readers. The appropriate context for understanding what I mean is an influential and authoritative thirteenth-century text, the Summa Theologiae by Thomas Aquinas. In Questions 92 to 95 of the Secunda secundae, Thomas sharply distinguished both of what we call astronomy and astrology from divination, in discussing legitimate and illegitimate modes of knowing and/or predicting the future. ${ }^{61}$ Although astrology is conjectural and not certain - like astronomy is - they are both legitimate modes of knowing and predicting because they both rely on causal knowledge. This is decidedly not the case with what Thomas explicitly calls divinatory practices - including augury and geomancy - which have no causal foundations, and thus rely solely on demons.

In the Disputations, then, Pico implicitly responded to and rejected Thomas's influential analysis, collapsing his careful distinctions, and casting astrology wholly into the snakepit of divinatory practices, which he would never dignify with the term arts. In their famous anti-divinatory papal bulls of 1586 and 1631, Sixtus V and Urban VIII both followed Pico in this rebranding effort. ${ }^{62}$ The equally influential Rule IX of the Index of Probibited Books (1564, 1596 and later), however, followed and expanded Thomas's views, thus setting up a conflict - valuable for us - between these two sets of legally binding texts, whose debates we can now see fully articulated in recently edited documents from the archives of the Roman Congregations of the Holy Office and the Index. ${ }^{63}$ Thomas Aquinas, then, was another major, fundamentally pro-astrological authority for Pico to co-opt, but also a complex one - as we can now more easily see - as was Thomas's distinguished teacher, Albertus Magnus; but these are topics for another occasion. ${ }^{64}$

Despite Pico's furious efforts at rebranding, then, astrology was still considered legitimate knowledge, and continued to be taught at the finest early mod-

${ }^{60}$ For Savonarola in context, see (e.g.) Weinstein, Savonarola and Florence, and Dall'Aglio, Savonarola, and for his relationship to both Giovanni and Gianfrancesco Pico, see Garfagnini, 'Savonarola tra Giovanni e Gianfrancesco Pico', pp. 237-79.

${ }^{61}$ I discuss this material in part 2 of volume I of my monograph Sapientia Astrologica, and more fully and in a broader context in my 'Is Astrology a Type of Divination?'.

${ }^{62}$ See (i.a.) Ernst, 'Dalla bolla Coeli et terrae', pp. 255-79.

${ }^{63}$ See Baldini and Spruit, Catholic Church and Modern Science, vol. I, tomes 1-4. Although the texts they publish are extremely valuable, their interpretations should be treated with caution.

${ }^{64}$ For both Thomas's and Albert's views on astrology — including in relation to theology - see volume I of my monograph Sapientia Astrologica. 
ern European universities, until well into the seventeenth century, and sometimes beyond. ${ }^{65}$ Nevertheless, Pico's Disputations Against Divinatory Astrology - with its complex and highly interested uses of Ptolemy - certainly played a significant cumulative role in astrology's eventual removal from the time-honored and well-established premodern maps of legitimate knowledge and practice. Further study should make that role more fully understood.

\section{Bibliography}

Adamson, Peter, and Peter E. Pormann, The Philosophical Works of Al-Kindī, Oxford: Oxford University Press, 2012.

Azzolini, Monica, The Duke and the Stars. Astrology and Politics in Renaissance Milan, Cambridge (Mass.): Harvard University Press, 2013.

Bacchelli, Franco, 'Appunti per la storia del testo delle Disputationes adversus astrologiam divinatricem', Dianoia 13 (2008), pp. 141-59.

Baldini, Ugo, and Leen Spruit (eds), Catholic Church and Modern Science. Documents from the Archives of the Roman Congregations of the Holy Office and the Index, vol. I, tomes 1-4: Sixteenth Century Documents, Roma: Libreria Editore Vaticana, 2009.

Bertozzi, Marco (ed.), Nello specchio del cielo. Giovanni Pico della Mirandola e le Disputationes contro l'astrologia divinatoria, Firenze: Olschki, 2008.

Bezza, Giuseppe, Arcana Mundi. Antologia del pensiero astrologico antico, 2 vols, Milano: Rizzoli, 1995.

Boer, Emilie, Ka@jós. Pseudo-Ptolemaei Fructus sive Centiloquium, Leipzig: Teubner, 1952 [Claudii Ptolemaei Opera quae exstant omnia, vol. III.2].

Boudet, Jean-Patrice, Entre science et nigromance. Astrologie, divination et magie dans l'Occident médiéval, XIIe-XVe siècle, Paris: Publications de la Sorbonne, 2006.

Boudet, Jean-Patrice, 'Nature et contre-nature dans l'astrologie médiévale. Le cas du Centiloquium du pseudo-Ptolémée', in Maaike van der Lugt (ed.), La nature comme source de la morale au Moyen Age, Firenze: SISMEL edizioni del Galluzzo, 2014, pp. 383-410.

Caroti, Stefano, 'Le fonti medievali delle Disputationes adversus astrologiam divinatricem', in Marco Bertozzi (ed.), Nello specchio del cielo. Giovanni Pico della Mirandola e le Disputationes contro l'astrologia divinatoria, Firenze: Olschki, 2008, pp. 67-94.

Dall'Aglio, Stefano, Savonarola and Savonarolism, tr. John Gagne, Toronto: Centre for Reformation and Renaissance Studies, 2010.

d'Alverny, Marie-Thérèse, and Françoise Hudry, 'Al-Kindi, De Radiis', Archives d'Histoire Doctrinale et Litteraire du Moyen Age 41 (1975), pp. 139-259.

${ }^{65}$ For the basic chronology, see my article 'Astrology' and now my 'How to Accurately Account'. 
Ernst, Germana, 'Dalla bolla Coeli et terrae all'Inscrutabilis. L'astrologia tra religione, natura e politica nell'età della Contrariforma', in Germana Ernst (ed.), Religione, ragione e natura. Ricerche su Tommaso Campanella e il tardo Rinascimento, Milano: Franco Angeli, 1991, pp. 255-79.

Farmer, Stephen A., Syncretism in the West: Pico's 900 theses (1486). The Evolution of Traditional, Religious, and Philosophical Systems, Tempe: Medieval and Renaissance Texts and Studies, 1998.

Federici Vescovini, Graziella, 'I programmi degli insegnamenti del Collegio di medicina, filosofia e astrologia dello statuto dell'università di Bologna del 1405', in Jacqueline Hamesse (ed.), Roma, magistra mundi. Itineraria culturae medievalis, Mélanges offerts au Père L. E. Boyle, Louvain-la-Neuve: Fédération des Instituts d'Etudes Médiévales, 1998, vol. I, pp. 193-223.

Garfagnini, Gian Carlo, 'Savonarola tra Giovanni e Gianfrancesco Pico', in Gian Carlo Garfagnini (ed.), Giovanni Pico della Mirandola. Convegno internazionale di studi nel 500 anniversario della morte (1494-1994), Mirandola, 4-8 ottobre 1994, Firenze: Olschki, 1997, pp. 237-79.

Garin, Eugenio, Giovanni Pico della Mirandola, Disputationes adversus astrologiam divinatricem, 2 vols, Firenze: Vallecchi, 1946-1952.

Gentile, Sebastiano, 'Pico e la biblioteca Medicea privata', in Paolo Viti (ed.), Pico, Poliziano e l'umanesimo di fine Quattrocento, Firenze: Olschki, 1994, pp. 85-101.

Gentile, Sebastiano, 'Pico filologo', in Gian Carlo Garfagnini (ed.), Giovanni Pico della Mirandola. Convegno internazionale di studi nel $500^{\circ}$ anniversario della morte (1494-1994), Mirandola, 4-8 ottobre 1994, Firenze: Olschki, 1997, pp. 465-90.

Grafton, Anthony, 'Giovanni Pico della Mirandola. Trials and Triumphs of an Omnivore', in Anthony Grafton (ed.), Commerce with the Classics. Ancient Books and Renaissance Readers, Ann Arbor: University of Michigan Press, 1997, pp. 93-134.

Grafton, Anthony, Cardano's Cosmos. The Worlds and Works of a Renaissance Astrologer, Cambridge (Mass.): Harvard University Press, 2001.

Green, Jonathan, Printing and Prophecy. Prognostication and Media Change 1450-1550, Ann Arbor: The University of Michigan Press, 2011.

Hasse, Dag Nikolaus, Success and Suppression. Arabic Sciences and Philosophy in the Renaissance, Cambridge (Mass.): Harvard University Press, 2016.

Heiberg, Johan L., Syntaxis mathematica, 2 vols, Leipzig: Teubner, 1898-1903 [Claudii Ptolemaei opera quae exstant omnia, vol. I].

Hossfeld, Paul (ed.), Albertus Magnus, Opera Omnia, vol. V.1: De caelo et mundo, Monasterii Westfalorum: Aschendorff, 1971; vol. V.2: De generatione et corruptione, Monasterii Westfalorum: Aschendorff, 1980.

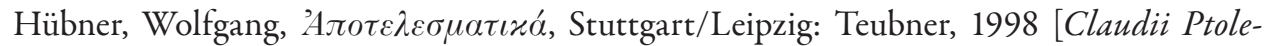
maei opera quae exstant omnia, vol. III.1].

Lemay, Richard, 'Origin and Success of the Kitāb Thamara of Abū Ja'far Aḥmad ibn Yūsuf ibn Ibrāhīm from the Tenth to the Seventeenth Century in the World 
of Islam and the Latin West', in Ahmad Y. al Hassan, Ghada Karmi and Nizar Namnum (eds), Proceedings of the First International Symposium for the History of Arabic Science (Aleppo, April 5-12, 1976), Aleppo: Institute for the History of Arabic Science, 1978, vol. II, pp. 91-107.

Mugnai Carrara, Daniela, La biblioteca di Nicolò Leoniceno. Tra Aristotele e Galeno: cultura e libri di un medico umanista, Firenze: Olschki, 1991.

Newman, William R., 'The Chymistry of Isaac Newton' (http://webappl.dlib.indiana. edu/newton/index.jsp).

Newman, William R., Newton the Alchemist: Science, Enigma, and the Quest for Nature's Fire, Chicago: University of Chicago Press, 2018.

North, John D., 'Astrology and the Fortunes of Churches', Centaurus 24 (1980), pp. 181-211.

Nothaft, Philipp, 'Vanitas vanitatum et super omnia vanitas. The Astronomer Heinrich Selder and a Newly Discovered Fourteenth-Century Critique of Astrology', Erudition and the Republic of Letters 1 (2016), pp. 261-304.

Pompeo Faracovi, Ornella, Gli oroscopi di Cristo, Venezia: Marsilio, 1999.

Pontano, Giovanni, Liber commentationum in Centum sententiis Ptolemaei, Basel: Andreas Cratander, 1531.

Ptolemy, Quadripartitum, tr. Plato of Tivoli, Venice, Erhardus Ratdolt, 1484.

Robbins, Frank E., Ptolemy. Tetrabiblos, Cambridge (Mass.): Harvard University Press, 1940.

Rutkin, H. Darrel, 'The Use and Abuse of Ptolemy's Tetrabiblos in Renaissance and Early Modern Europe. Two Case Studies (Giovanni Pico della Mirandola and Filippo Fantoni)', in Alexander Jones (ed.), Ptolemy in Perspective. Use and Criticism of his Work from Antiquity to the Nineteenth Century, Dordrecht: Springer, 2010, pp. 135-49.

Rutkin, H. Darel, Astrology, Natural Philosophy and the History of Science, c. 1250-1700: Studies toward an Interpretation of Giovanni Pico della Mirandola's Disputationes adversus astrologiam divinatricem, PhD dissertation, Indiana University, 2002.

Rutkin, H. Darrel, 'Astrology', in Lorraine Daston and Katharine Park (eds), The Cambridge History of Science, vol. III, Cambridge: Cambridge University Press, 2006, pp. 541-61.

Rutkin, H. Darrel, 'Astrology and Magic', in Irven M. Resnick (ed.), A Companion to Albert the Great. Theology, Philosophy and the Sciences, Leiden: Brill, 2013, pp. 451-505.

Rutkin, H. Darrel, 'How to Accurately Account for Astrology's Marginalization in the History of Science and Culture: The Essential Importance of an Interpretive Framework', in a special issue of Early Science and Medicine edited by Hiro Hirai and Rienk Vermij, 23 (2018), pp. 217-43.

Rutkin, H. Darrel, 'Is Astrology a Type of Divination?: Thomas Aquinas, the Index of Prohibited Books and the Construction of a Legitimate Astrology in the Middle 
Ages and the Renaissance', International Journal of Divination \& Prognostication 1 (2019), pp. 36-74.

Rutkin, H. Darrel, Sapientia Astrologica: Astrology, Magic and Natural Knowledge, ca. 1250-1800, Vol. I: Medieval Structures (1250-1500): Conceptual, Institutional, Socio-Political, Theologico-Religious and Cultural, Dordrecht: Springer, 2019; vol. II: Renaissance Structures (1480-1500): Continuities and Transformations, in process.

Simon, Gérard, Kepler astronome, astrologue, Paris: Gallimard, 1979.

Toomer, Gerald J., Ptolemy's Almagest, London/New York: Duckworth / Springer, 1984.

Tur, Alexandre, Hora introitus solis in Arietem. Les prédictions astrologiques annuelles latines dans l'Europe du XVe siècle (1405-1484), Thèse de Doctorat, Université d'Orléans, 2018.

Weinstein, Donald, Savonarola and Florence. Prophecy and Patriotism in the Renaissance, Princeton: Princeton University Press, 1970.

Westman, Robert S., The Copernican Question. Prognostication, Skepticism and Celestial Order, Berkeley: University of California Press, 2011.

Zambelli, Paola, 'Giovanni Mainardi e la polemica sull'astrologia', in L'opera e il pensiero di Giovanni Pico della Mirandola nella storia dell'umanesimo. Convegno internazionale per il $V$ Centenario della nascita di Giovanni Pico della Mirandola (Mirandola, 15-18 settembre 1963), vol. II, Firenze: Olschki, 1965, pp. 205-79 [reprinted in her L'ambigua natura della magia: Filosofi, streghe, riti nel Rinascimento, Venezia: Marsilio, 1996, pp. 76-118]. 